\title{
Influence of poultry litter and plant density on the production and chemical composition of the essential oil of Schinus terebinthifolius Raddi fruits
}

\author{
TABALDI, L.A. ${ }^{*}$; VIEIRA, M.C. ${ }^{2} ;$ ZÁRATE, N.A.H. ${ }^{2}$; FORMAGIO, A.S.N. ${ }^{2}$; PILECCO, M. ${ }^{3}$; SILVA, L.R. ${ }^{4}$; SANTOS, \\ K.P. ${ }^{5}$ \\ ${ }^{1}$ Departamento de Biologia, Universidade Federal de Santa Maria (UFSM), Santa Maria, RS, Brasil. *E-mail: \\ lutabaldi@yahoo.com.br; '2Faculdade de Ciências Agrárias (FCA), Universidade Federal da Grande Dourados

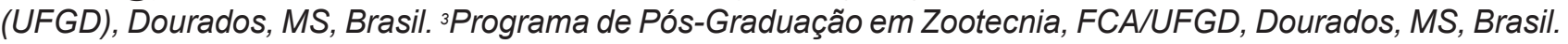 \\ ${ }^{4}$ Graduação em Engenharia de Alimentos, UFGD. Dourados, MS, Brasil; " ${ }^{5}$ Graduação em Engenharia Agrícola. \\ UFGD, Dourados, MS, Brasil.
}

\begin{abstract}
The aim of this study was to evaluate the production and chemical composition of the essential oil of Brazilian pepper fruits grown in single and double rows using different doses of semi decomposed poultry litter in two evaluation times. The experiment was carried out at the Federal University of Grande Dourados, in the city of Dourados, state o- Mato Grosso do Sul, Brazil, from October 2009 to November 2010. Brazilian pepper plants were grown in single and double rows in soil with incorporated poultry litter at the doses of $0,5,10,15$ and $20 \mathrm{tha}^{-1}$. Treatments were arranged as a $2 \times 5$ factorial experiment in a randomized block design with four replications. Fruits were harvested 180 and 390 days after transplant (DAT). There was a significant interaction for fresh weight of fruits and weight of 50 fruits, being the values higher at 180 DAT in the double rows with increasing poultry litter doses. Fruits harvested 390 DAT showed higher diameter compared with those harvested 180 DAT. The number of fruits per bunch was significantly influenced by the doses of poultry litter, presenting a linear increase with increasing doses. The essential oil of the Brazilian pepper fruits obtained by hydrodistillation and analyzed by Gas chromatography-mass spectrometry exhibited predominance of monoterpenes, highlighting a-pinene $(20.14 \%)$ as the major constituent. The chemical composition of the essential oil was not influenced by the number of plant rows in the plot or by the doses of poultry litter in any evaluation time. Therefore, the cultivation of Brazilian pepper plants is recommended in double rows, with $13.59 \mathrm{t} \mathrm{ha}^{-1}$ of incorporated poultry litter in the soi, and with harvest of 180 DAT for higher fruit production.
\end{abstract}

Keywords: Brazilian pepper; organic waste; medicinal plant; plant densities.

RESUMO: Influência da cama-de-frango e densidade de plantas na produção e composição química do óleo essencial de frutos de Schinus terebinthifolius Raddi. O objetivo deste estudo foi avaliar a produção e composição química do óleo essencial de frutos de pimenta-rosa cultivados em fileira simples e dupla com diferentes doses de cama-de-frango semidecomposta em duas épocas de avaliação. O experimento foi realizado na Universidade Federal da Grande Dourados, em Dourados/MS, de outubro de 2009 a novembro de 2010. Plantas de pimentarosa foram cultivadas em fileira simples e dupla, em solo com cama-de-frango incorporada nas doses de $0,5,10,15$ e $20 \mathrm{t} \mathrm{ha}^{-1}$. Os tratamentos foram arranjados em fatorial $2 \times 5$, em delineamento de blocos ao acaso com quatro repetições. Os frutos foram colhidos aos $180 \mathrm{e}$ 390 dias após o transplante (DAT). Houve interação significativa para peso fresco de frutos e peso de 50 frutos, sendo os valores maiores aos 180 DAT nas plantas cultivadas em fileira dupla, relacionado com o aumento das doses de cama-de-frango. Os frutos colhidos aos 390 DAT apresentaram maior diâmetro comparado com aqueles coletados aos 180 DAT. O número de frutos por cacho foi influenciado significativamente pelas doses de cama-de-frango, tendo aumento linear em função do aumento das doses. O óleo essencial dos frutos de pimenta-rosa obtido por hidrodestilação e analisado por cromatografia gasosa-espectrometria de massas exibiu predominância de monoterpenos, apresentando como principal constituinte o a-pineno $(20,14 \%)$. A composição química do óleo essencial não foi influenciada pelo número de fileiras de plantas na parcela, nem pelas doses de cama-de-frango, em nenhuma das épocas de avaliação.

Rev. Bras. PI. Med., Campinas, v.16, n.2, supl. I, p.398-405, 2014. 
Portanto, para maior produção de frutos recomenda-se o cultivo de plantas de pimenta-rosa em fileira dupla e $13.59 \mathrm{t} \mathrm{ha}^{-1}$ de cama-de-frango incorporada ao solo com colheita aos 180 DAT.

Palavras-chave: Pimenta-rosa; resíduo orgânico; planta medicinal; densidade de plantas.

\section{INTRODUCTION}

Recent movements towards naturally managed and the growing interest in managing environmental impacts of agriculture have led to the development of organic and natural fertilizers that may be suitable for commercial use. Some common materials used as organic fertilizer sources include manure-based materials (Gaskell et al., 2006; Hartz \& Johnstone, 2006), such as poultry litter. Poultry litter is a valuable source of major plant nutrients and has been used as a soil amendment in agriculture (Jalali \& Khanboluki, 2008). It contains high concentrations of C, N, P, $\mathrm{K}$, and other nutrients (Mullins \& Bendfeldt, 2001). Being a source of organic matter, poultry litter can interfere directly in the growth and production of fruits and in the partition of assimilates, besides affecting the chemical constitution of these fruits. However, the use of poultry litter as a source of nutrients and organic matter for medicinal plants has not been extensive.

Schinus terebinthifolius Raddi (Anacardiaceae), popularly called pink pepper or Brazilian pepper, and "pimenta rosa" or "aroeira pimenteira" in Brazil (Pires et al., 2004), is a perennial tree occurring in the Brazilian coast, recognized for presenting medicinal importance (Azevedo \& Silva, 2006) as well as for having ability to take root in disturbed areas (Carvalho, 1994). This species is also very important for the forest dynamics and regeneration because it attracts native animals such as birds and mammals (Carvalho, 1994; Barbosa \& Pizo, 2006). A single tree of pink pepper produces annually tens of thousands of single-seeded, small, fleshy, red fruits (drupes) between November and February. The consumption of pink pepper fruits has increased greatly, both in the international and national market that use them as food condiment (Lenzi \& Orth, 2004), as cosmetology components, and in the perfume industry (Moneam \& Ghoneim, 1986). The little seed has a mild flavor and is slightly spicy, being used in various preparations in the form of whole grains or ground (Lenzi \& Orth, 2004).

The importance of this plant has promoted its inclusion in the Brazilian Pharmacopeia (Brandão et al., 2006) and in the National List of Medicinal Plants, which has medicinal plants with potential to generate products of interest to SUS (Unified Health System) (RENISUS, 2009). Virtually, all parts of this tropical tree such as leaves, bark, fruit, seeds, resin, and oleoresin (or balsam) have been used medicinally by indigenous peoples throughout the tropical regions (El-Massry et al., 2009). Leaves, fruit and bark have antimicrobial, analgesic, antiinflammatory, antioxidant, anti-allergic, anti-free radical, and insecticidal activities (Di Stasi et al., 2002; Degáspari et al., 2005; Ceruks et al., 2007; Cavalher-Machado et al., 2008). To leaves and fruits are assigned antibiotic properties (Watt \& Breyer-Brandwijk, 1962). Moreover, fruits are rich in tannins, flavonoids and essential oil (Richter et al., 2010). Accordingly, information on the effects of organic matter on the content and on the composition of essential oil is crucial to optimize management protocols.

Pink pepper has been frequently studied from a chemical viewpoint (Degaspari et al., 2005; Ceruks et al., 2007; Lima et al., 2009; Richter et al., 2010), but there is a lack of detailed agronomic studies in literature aiming higher production of fruits and secondary metabolites of medicinal interest. In view of the lack of standardization, the low quality, and the low content of active principles of plant material available in the national and international market (Gobbo-Neto \& Lopes, 2007), the complementation with organic matter may contribute to the adequate production of medicinal plants and may influence the quantity and quality of essential oils as well as their biological action. Nutrient availability and plant density are important factors that lead to size differences (Müller et al., 2000 ) and variation in reproduction (Xiao et al., 2006). The best understanding of this interaction allows improving the handling of the culture leading to higher productivity with better quality of product and minor environmental impact. Therefore, the aim of this study was to evaluate the production and chemical composition of the essential oil of pink pepper fruits grown in single and double rows using different doses of semi decomposed poultry litter in two evaluation times.

\section{MATERIAL AND METHOD}

The experiment was carried out at the Federal University of Grande Dourados in an area located at $22^{\circ} 11^{\prime} 44^{\prime \prime} S$ of latitude, $54^{\circ} 56^{\prime} 07^{\prime \prime} \mathrm{W}$ of longitude and $452 \mathrm{~m}$ of altitude, from October 2009 to November 2010. The climate of Dourados, according to Köppen, is mesothermal humid, Cwa type, with temperature and annual rainfall averages ranging

Rev. Bras. PI. Med., Campinas, v.16, n.2, supl. I, p.398-405, 2014. 
from $20^{\circ}$ to $24^{\circ} \mathrm{C}$ and $1250-1500 \mathrm{~mm}$, respectively. The soil, originally under Cerrado vegetation, is classified as a dystrophic red oxisol of clayey texture. Before the experiment, soil samples were collected $(0-20 \mathrm{~cm}$ soil depth) for the determination of the chemical characteristics, which showed the following results: 4.92 of $\mathrm{pH}\left(\mathrm{H}_{2} \mathrm{O}\right) ; 28.9 \mathrm{~g} \mathrm{dm}^{-3}$ of organic matter; $12.59 \mathrm{mg} \mathrm{dm}^{-3}$ of $\mathrm{P} ; 4.7 \mathrm{mmol}_{\mathrm{c}} \mathrm{dm}^{-3}$ of $\mathrm{K} ; 0.0$ $\mathrm{mmol}_{\mathrm{c}} \mathrm{dm}^{-3}$ of Al; $25.0 \mathrm{mmol}_{\mathrm{c}} \mathrm{dm}^{-3}$ of $\mathrm{Ca}$ and 17.0 $\mathrm{mmol}_{\mathrm{c}} \mathrm{dm}^{-3}$ of $\mathrm{Mg}$, and $45 \%$ of saturation.

The spread of pink pepper (Schinus terebinthifolius Raddi, Anacardiaceae) was performed by indirect sowing with seeds released from the exocarps in July 2009. Seeds of pink pepper were collected in native areas of the state of MS in January 2009. A voucher specimen was deposited in the herbarium of the Faculty of Biological Sciences of UFGD (DDMS 4602). Seedlings were produced initially in polystyrene trays with 128 cells, with Plantmax ${ }^{\otimes}$ substrate, kept in the greenhouse with shade $50 \%$, with daily irrigation, and transplanted to the field when the seedlings were about $15 \mathrm{~cm}$ high (70 days after sowing).

Pink pepper was grown in single and double rows in soil with incorporated semi decomposed poultry litter at doses of $0,5,10,15$ and $20 \mathrm{t} \mathrm{ha}^{-1}$. Analyses of the semi decomposed poultry litter showed the following chemical characteristics: 7.14 of $\mathrm{pH} ; 20.74,52.66,6.21,1.03,0.85,3.15,0.54$, and $3.07 \%$ of total moisture, organic matter, $\mathrm{Ca}, \mathrm{Mg}, \mathrm{K}, \mathrm{N}$, $\mathrm{Al}$, and $\mathrm{P}$, respectively; and 8.75 of $\mathrm{C} / \mathrm{N}$. Treatments were arranged as $2 \times 5$ factorial, in a randomized block design with four replications. Each plot was $2.5 \mathrm{~m}$ long $\times 1.0 \mathrm{~m}$ wide, with five plants arranged in single row and 10 plants in double row, with spacing of $0.5 \mathrm{~m}$ between plants, totalizing populations of 13.200 and 26.400 plants ha-1 $^{-1}$, respectively.

The soil was prepared in the previous day of the plantation with one plowing and harrowing and subsequently elevation of plots with a bedshaper rotary cultivator offset and incorporation of the poultry litter in the corresponding doses to each treatment. Irrigations were made using the sprinkler system whenever necessary. Spontaneous vegetation was controlled by weeding with hoe between the plots and manually within the plots.

We evaluated the fresh weight of fruits, fruit diameter, number of fruits per bunch, weight of 50 fruits, and chemical composition of fruit essential oil 180 and 390 days after transplant (DAT), with results expressed by plant. For the determination of the chemical composition of essential oil, ripe fruits were subjected to hydrodistillation for $3 \mathrm{~h}$ using a Clevenger-type apparatus. The oil was dried over anhydrous sodium sulphate and preserved in a sealed vial at $4^{\circ} \mathrm{C}$ until further analysis.

Analyses were performed on a gas chromatograph (GC 3900) equipped with ion-trap mass spectrometer detector (Varian Saturn 2100), using DB-5 (5\% de phenyl dimethylpolysiloxane) and fused-silica column $(30 \mathrm{~m} \times 0.25 \mathrm{~mm}, 0.25$ $\mu \mathrm{m}$ film thickness) under the following conditions: carrier gas helium $(99.999 \%$, flow rate $1.0 \mathrm{~mL}$

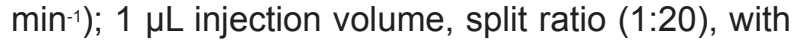
initial oven temperature of $40^{\circ} \mathrm{C}$ and heating from $40-250^{\circ} \mathrm{C}$ at $3^{\circ} \mathrm{C} / \mathrm{min}$. The injector temperature and quadruple detector temperature were $250^{\circ} \mathrm{C}$ and line transfer $250^{\circ} \mathrm{C}$. The MS scan parameters included electron impact ionization voltage at $70 \mathrm{eV}$, a mass range of 40 to $650 \mathrm{~m} / \mathrm{z}$ and a scan interval of $0.5 \mathrm{~s}$. Temperature-programmed retention indices (Isidorov et al., 1998) were calculated using a mixture of normal paraffin (C8-C25) as external references. The identifications were completed by comparing the spectra of masses obtained with those of NIST 2.0, Saturn Libraries and literature data (Adams, 2001). The determination of the relative area by GC/FID analyses was performed using a gas chromatograph GC-17A (Shimadzu) equipped with the same DB-5 fused silica column capillary and in the same conditions of Gas chromatography-mass spectrometry (GC/MS).

Data were subjected to analysis of variance, and when significance was found by $F$ test, data were subjected to regression analysis or Tukey test by $5 \%$ probability, with the SOC statistic package (Scientific Software: NTIA/EMBRAPA).

\section{RESULTS AND DISCUSSION}

Fresh weight of fruit plant-1 and weight of 50 fruits were significantly influenced by the interaction of factors such as evaluation times, doses of poultry litter, and number of plant rows in the plot. The fresh weight of fruit plant ${ }^{-1}$ (Figure 1a) showed a quadratic increase 180 days after transplant (DAT) with increasing poultry litter doses, reaching maximum production of $470.85 \mathrm{~g} \mathrm{plant}^{-1}$ at $13.59 \mathrm{t}$ ha-1 of poultry litter, and a linear increase 390 DAT, reaching maximum production of $43.23 \mathrm{~g} \mathrm{plant}^{-1}$ at 20 t ha $^{-1}$. Findings obtained (180 DAT) are consistent with results from other studies which have shown that excessive organic fertilizer depresses plant growth compared with lower fertility levels (Kelley \& Biernbaum, 2000; Carpio et al., 2005).

Fresh weight of fruit plant-1 (Figure 1a) and weight of 50 fruits (Figure $1 \mathrm{~b}$ ) were higher at 180 DAT compared with 390 DAT. Flower and fruit production and the consequent seed dispersion are likely to be altered due to climate change (Ogaya \& Peñuelas, 2007). Thus, these data suggest that environmental factors may affect yield rates of pink pepper fruits, since the pink pepper plants passed by a period of winter after the first harvest. Low temperatures during

Rev. Bras. PI. Med., Campinas, v.16, n.2, supl. I, p.398-405, 2014. 
this season probably did not favor the photosynthesis and continued plant growth, flowering, and fruit set, which reflects the basal metabolism of the plants with maintenance respiration.

The weight of 50 fruits increased linearly with increasing doses of poultry litter 180 DAT and 390 DAT, with maximum weight of $3.84 \mathrm{~g}$ and 1.71 $\mathrm{g}$, respectively, at $20 \mathrm{t} \mathrm{ha}^{-1}$ (Figure $1 \mathrm{~b}$ ). Poultry litter adds nutrients and organic matter to the soil, increasing its fertility (Belefant-Miller, 2007). Moreover, the partitioning of dry matter among various organs depends on their sink strength, i.e., their competitive ability to attract assimilates (Marcelis, 1996), indicating that the fruits had higher sink strength 180 DAT.

Fresh weight of fruit plant ${ }^{-1}$ showed a quadratic increase with increasing poultry litter doses in both plant densities (Figure 2a). The maximum production of fresh weight of fruits was 496.10 and 511.33 g plant $^{-1}$ at 16.16 and $12.71 \mathrm{t} \mathrm{ha}^{-1}$ of poultry litter to single and double rows, respectively. Similarly, the weight of 50 fruits was higher in plants growing in double rows with low and intermediary doses of poultry litter, compared with single rows (Figure 2b). However, at $20 \mathrm{t} \mathrm{ha}^{-1}$, the weight of 50 fruits was similar, with maximum weight of $5.61 \mathrm{~g}$ and $5.56 \mathrm{~g}$ in simple and double rows, respectively. This finding indicates that there was no competition for light, water or nutrients between plants at higher density. According to Barbedo et al. (2000), one of the cultural practices that may influence the production of medicinal plants is the density or arrangement of plants, favoring a better use of light, water and nutrients, and increasing the yield and the quality of the product. Thus, in this work, the cultivation of pink pepper plants in double row can be recommended.

Fresh weight of fruit plant ${ }^{-1}$ and 50 fruits weight were higher in plants growing in double row 180 DAT compared with simple row (Table 1). This may have occurred due to the increased shading caused by the higher plant density, keeping the soil with greater moisture, which benefits plant growth and microbial activity. On the other hand, at 390 DAT, the number of plant rows in the plot influenced only the fresh weight of fruit plant ${ }^{-1}$, which was $80.75 \mathrm{~g}$ plant ${ }^{-1}(+103,51 \%)$ higher under simple row (Table 1$)$. This probably is the result of the source-sink balance during the growth of plants.

The distribution of assimilates in fruit crops can affect total fruit production as well as fruit size and quality. For fruit diameter, there was a significant interaction only between the doses of poultry litter and evaluation times (Figure 3a). The fruit diameter, at 180 DAT, showed a quadratic response with increasing doses of poultry litter, while 390 DAT there was a linear increase in the fruit diameter with increasing doses of poultry litter. Moreover, fruits harvested 390 DAT showed higher diameter compared with those collected 180 DAT, with maximum diameter of 5.84 and $5.17 \mathrm{~mm}$, respectively, at $20 \mathrm{t} \mathrm{ha}^{-1}$. These findings show that the increase in the total production of fruit 180 DAT (Figure 1a) was not due to an increase in the fruit diameter. A greater number of fruits is able to attract more assimilates but with decreasing efficiency as the average fruit weight decreases.
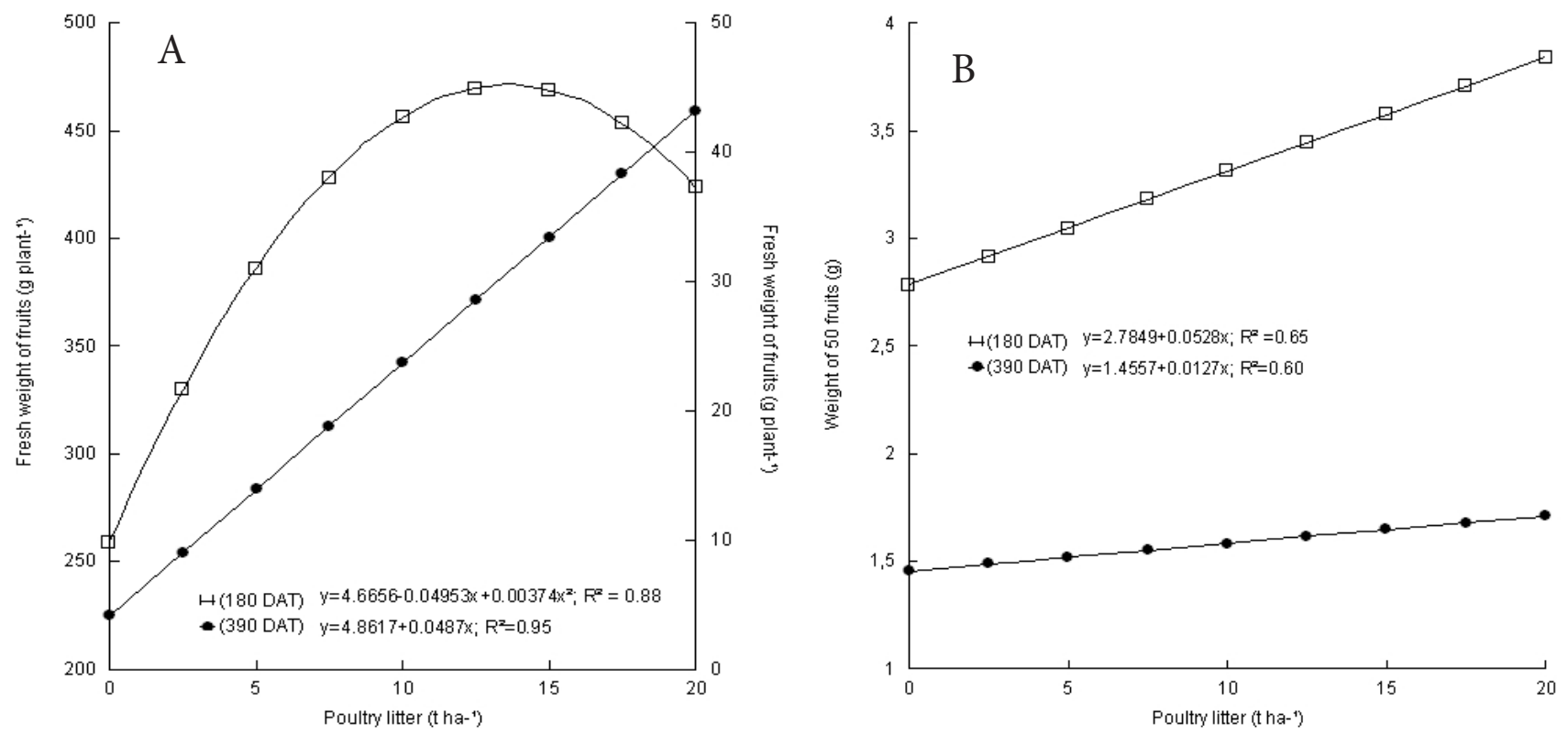

FIGURE 1. Fresh weight of fruit plant-1 (a) and 50 fruits weight (b) of pink pepper plants as a function of poultry litter doses and evaluation times.

Rev. Bras. PI. Med., Campinas, v.16, n.2, supl. I, p.398-405, 2014. 

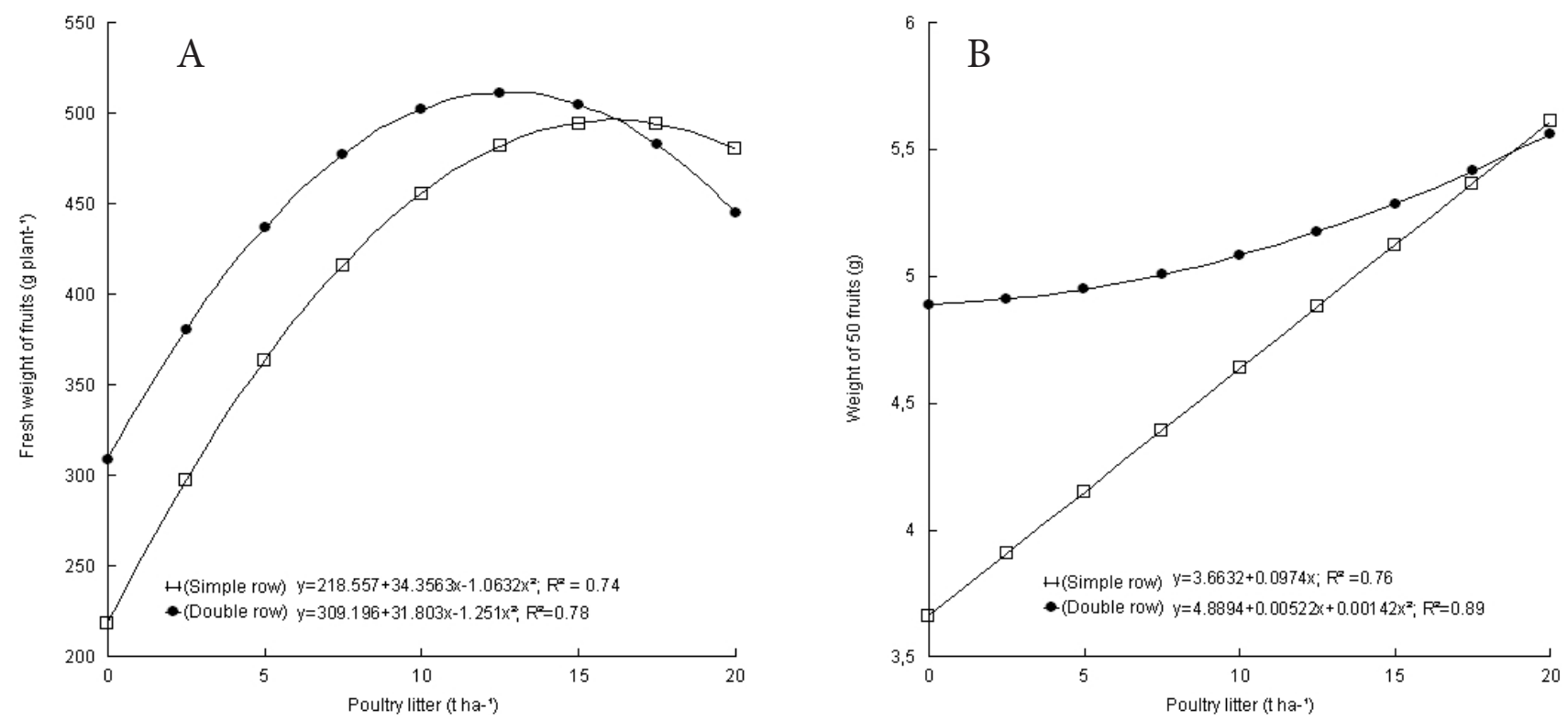

FIGURE 2. Fresh weight of fruit plant ${ }^{-1}$ (a) and 50 fruits weight (b) of pink pepper plants as a function of poultry litter doses and plant rows in the plot.

TABLE 1. Fresh weight of fruit plant-1 and 50 fruits weight of pink pepper plants as a function of the interaction between evaluation times and rows of plants in the plot.

\begin{tabular}{lllll}
\hline & 180 DAT & & 390 DAT & \\
\hline Rows of plants & Fresh weight of & 50 fruits & Fresh weight & 50 fruits \\
in the plot & fruits $\left(\mathrm{g}\right.$ plant $\left.{ }^{-1}\right)$ & weight $(\mathrm{g})$ & of fruits $\left(\mathrm{g}\right.$ plant $\left.{ }^{-1}\right)$ & weight $(\mathrm{g})$ \\
\hline Simple row & $1867.3 \pm 161 \mathrm{~b}$ & $15.191 \pm 0.5 \mathrm{~b}$ & $158.76 \pm 20.5 \mathrm{a}$ & $7.997 \pm 0.5 \mathrm{a}$ \\
Double row & $2119.6 \pm 108 \mathrm{a}$ & $17.933 \pm 1.1 \mathrm{a}$ & $78.01 \pm 10.01 \mathrm{~b}$ & $7.830 \pm 0.3 \mathrm{a}$ \\
\hline
\end{tabular}

Means followed by same letter in each column do not differ at $5 \%$ probability by Tukey test.

The number of fruits per bunch was significantly influenced by doses of poultry litter, where there was a linear increase with increasing doses (Figure $3 \mathrm{~b}$ ), with maximum yield of 57.95 fruits per bunch at $20 \mathrm{t} \mathrm{ha}^{-1}$. This increase is probably due to the release of nutrients and organic matter from the poultry litter. Thus, poultry litter may be an efficient tool to increase the fruit yield of pink pepper, supplying nutrient to the plants and improving the physical and chemical characteristics of the soil.

Although many differences were found in the fruit yield, lower differences in the fruit quantitative chemical composition were found in plants grown in different plant densities and poultry litter doses (Table 2). By hydrodistillation, the ripe fruits of pink pepper produced $9.2 \%(\mathrm{v} / \mathrm{w})$ of essential oil. Components of the studied essential oil are shown in Table 2. The quantitative chemical composition of essential oil of pink pepper fruits was influenced only by different doses of poultry litter, with increase in a-fenchene, $\alpha$-copaene and $\alpha$-funebrene concentration and reduction in longievene, biciclogermacrene and aromadendrene with the increase of poultry litter doses.

Seventeen compounds, representing $98.55 \%$ of the oil, were identified with a predominance of monoterpenes, highlighting a-pinene (20.67$20.14 \%$ ) as the major constituent. Other constituents at higher concentrations in our study were b-pinene (13.56-13.20\%), z-salven (11.01-10.75\%), sabinene (10.34-9.98\%), limonene (7.90-8.18\%), sphatulenol $(6.82-7.03 \%)$, and $\alpha$-copaene $(6.23-5.98 \%)$. Monoterpenes found in this essential oil may act as radical scavenging agents. It seems to be a general trend that the essential oils, which contain monoterpene hydrocarbons, oxygenated monoterpenes and/or sesquiterpenes, have greater antioxidative properties (Tepe et al., 2004; Mau et al., 2003).

When compared to literature data (Almeida et al., 2010; Richter et al., 2010; Affonso et al., 2011), our study evidenced some differences in the chromatographic profile as well as in the quantitative composition of pink pepper essential oil. In other 

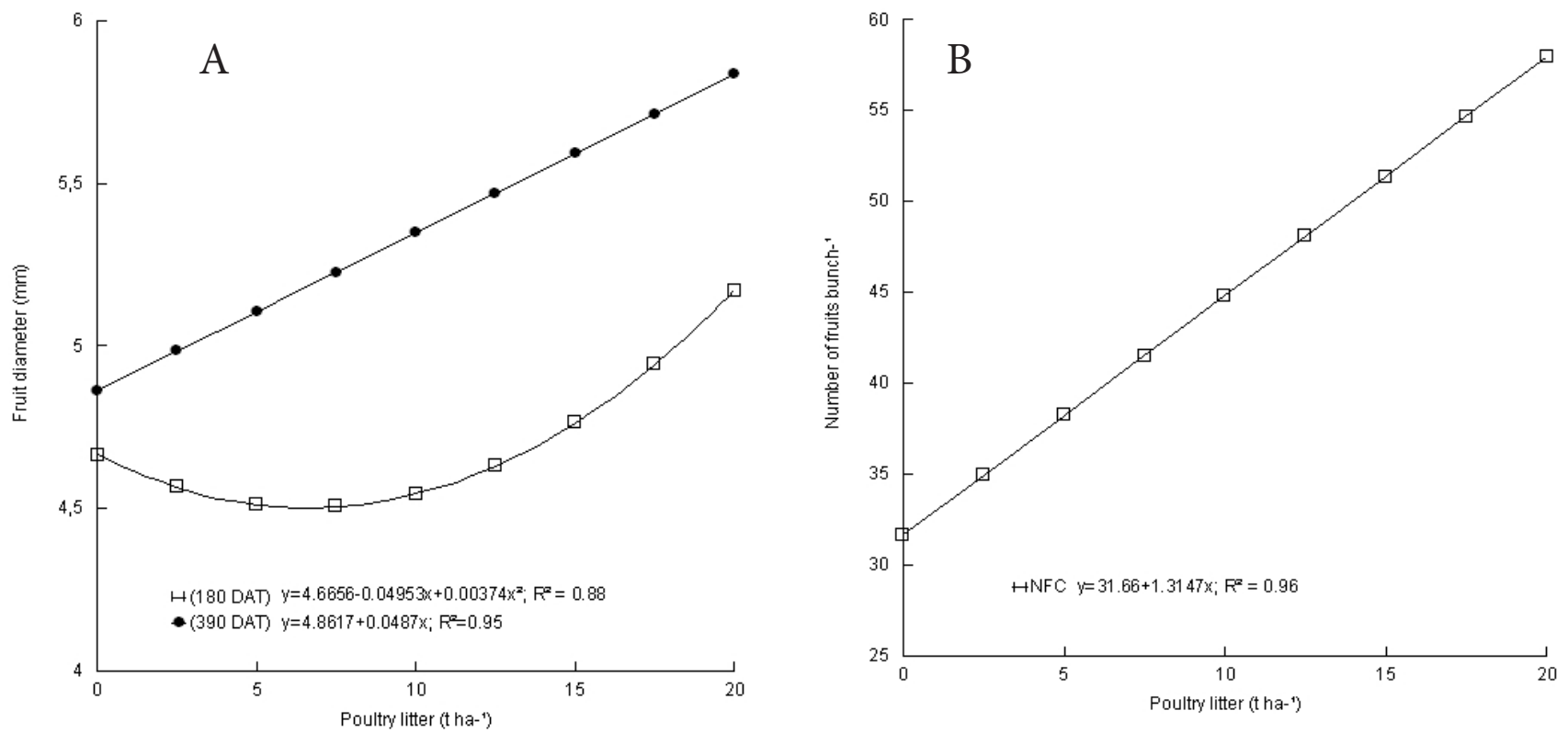

FIGURE 3. Fruit diameter (a) of pink pepper plants as a function of poultry litter doses and evaluation times and number of fruit bunch-1 (b) as a function of poultry litter doses.

TABLE 2. Chemical composition of the essential oil of pink pepper fruits determined by gas chromatography coupled to mass spectrometry.

\begin{tabular}{|c|c|c|c|c|c|c|c|c|c|c|c|}
\hline \multirow[b]{3}{*}{ Compound (\%) } & \multirow[b]{3}{*}{$\mathbf{R I}^{*}$} & \multicolumn{10}{|c|}{ Poultry litter (t ha-1) } \\
\hline & & \multicolumn{2}{|c|}{0} & \multicolumn{2}{|c|}{5} & \multicolumn{2}{|c|}{10} & \multicolumn{2}{|c|}{15} & \multicolumn{2}{|c|}{20} \\
\hline & & s & D & S & D & S & D & s & D & S & D \\
\hline z-salvene & 856 & 11.0 & 11.0 & 11.0 & 11.0 & 10.9 & 10.9 & 10.8 & 10.8 & 10.8 & 10.8 \\
\hline a-pinene & 939 & 20.7 & 20.6 & 20.6 & 20.5 & 20.4 & 20.3 & 20.3 & 20.3 & 20.2 & 20.1 \\
\hline a-Fenchene & 953 & 2.9 & 3.0 & 3.1 & 3.2 & 3.3 & 3.5 & 3.7 & 3.8 & 4.0 & 4.1 \\
\hline Sabinene & 975 & 10.0 & 10.1 & 10.1 & 10.2 & 10.2 & 10.3 & 10.3 & 10.3 & 10.3 & 10.3 \\
\hline$\beta$-Pinene & 980 & 13.6 & 13.5 & 13.5 & 13.5 & 13.4 & 13.4 & 13.3 & 13.3 & 13.3 & 13.2 \\
\hline Limonene & 1030 & 8.2 & 8.1 & 8.1 & 8.1 & 8.1 & 8.1 & 8.0 & 8.0 & 8.0 & 7.9 \\
\hline Terpinen-4-ol & 1182 & 1.6 & 1.6 & 1.6 & 1.6 & 1.5 & 1.5 & 1.5 & 1.5 & 1.5 & 1.5 \\
\hline Neo-iso-Verbanol & 1189 & 1.2 & 1.2 & 1.1 & 1.1 & 1.1 & 1.1 & 1.1 & 1.1 & 1.1 & 1.1 \\
\hline z-patchenol & 1319 & 1.8 & 1.8 & 1.8 & 1.8 & 1.7 & 1.7 & 1.7 & 1.7 & 1.7 & 1.7 \\
\hline Longieyelene & 1375 & 2.9 & 2.8 & 2.8 & 2.8 & 2.8 & 2.8 & 2.8 & 2.7 & 2.7 & 2.7 \\
\hline a-Copaene & 1377 & 6.0 & 6.0 & 6.1 & 6.1 & 6.1 & 6.1 & 6.2 & 6.2 & 6.2 & 6.2 \\
\hline$\alpha$-Funebrene & 1403 & 1.9 & 1.9 & 2.0 & 2.0 & 2.3 & 2.3 & 2.4 & 2.5 & 2.5 & 2.7 \\
\hline Aromadendrene & 1465 & 2.8 & 2.7 & 2.7 & 2.6 & 2.6 & 2.6 & 2.5 & 2.5 & 2.5 & 2.4 \\
\hline Germacrene D & 1485 & 2.8 & 2.8 & 2.7 & 2.7 & 2.7 & 2.7 & 2.7 & 2.7 & 2.6 & 2.6 \\
\hline Biciclogermacrene & 1517 & 1.4 & 1.4 & 1.4 & 1.4 & 1.3 & 1.3 & 1.3 & 1.3 & 1.3 & 1.3 \\
\hline$\delta$-cadineno & 1519 & 3.0 & 3.0 & 2.9 & 2.9 & 2.9 & 2.9 & 2.9 & 2.9 & 2.9 & 2.8 \\
\hline Sphatulenol & 1619 & 7.0 & 7.0 & 7.0 & 7.0 & 7.0 & 6.9 & 6.9 & 6.9 & 6.9 & 6.8 \\
\hline
\end{tabular}

${ }^{*}$ RI: Retention Index; S: Simple Row; D: Double Row

studies, pink pepper fruits showed a-phellandrene (21.1\%), limonene (23.7\%) (Richter et al., 2010), d-3-carene (55.43\%) (Almeida et al., 2010), and a-fenchene (20.75\%) (Affonso et al., 2011) as main constituents. This was probably because of the changes in the quantity and quality of the oil constituents caused by different environmental factors related to soil, sun exposure, amount of water, and other external factors. Such variations between the chemical compositions of the similar plants from different geographical areas may also have an impact on the biological activities of the plant essential oils and extracts. Thus, plants found in different geographic regions may have different 
medicinal properties based on the difference in the chemical composition of the plants (Gundidza et al., 2009).

The results of this study showed that an increase in the plant density and in poultry litter doses incorporated in soil until 13.59 tha-1 $^{-1}$ positively influenced the fresh weight of fruit plant-1 and weight of 50 fruits. Because of this, pink pepper can be grown in double row and with poultry litter incorporated, seeking the efficient use of land.

Therefore, in the conditions under which the experiment was developed it is recommended the cultivation of pink pepper plants under double row and $13.59 \mathrm{t}$ ha-1 of poultry litter of incorporated poultry litter in soil, with harvest at 180 DAT for higher fruit production.

\section{REFERENCE}

ADAMS, R.P. Identification of essential oil components by Gas Chromatography Mass Spectroscopy.3.ed. Allured Publishing Corporation:Carol Stream, IL, 2001. 423p.

AFFONSO, C.R.G. et al. Effects of the essential oil from fruits of Schinus terebinthifolius Raddi (Anacardiaceae) on reproductive functions in male rats. Journal of the Brazilian Chemical Society, v.00, n.00, p.1-6, 2011.

ALMEIDA, D.L. et al. The essential oil of Brazilian pepper, Schinus terebinthifolia Raddi in larval control of Stegomyia aegypti (Linnaeus, 1762). Parasites \& Vectors, v.3, n.27, p.79-85, 2010.

AZEVEDO, S.K.S.; SILVA, I.M. Plantas medicinais e de uso religioso comercializadas em mercados e feiras livres no Rio de Janeiro, RJ, Brasil. Acta Botanica Brasilica, v.20, p.185-194, 2006.

BARBEDO, A.S.C. et al. População de plantas, método de colheita e qualidade de sementes de cenoura, cultivar Brasília. Pesquisa Agropecuária Brasileira, v.35, p.1645-1652, 2000.

BARBOSA, K.C.; PIZO, M.A. Seed, rain and seed limitation in a planted gallery forest in Brazil. Restor Ecology, v.14, p.504-515, 2006.

BRANDÃO, M.G.L. et al. Medicinal plants and other botanical products from the Brazilian Official Farmacopoeia. Brazilian Journal of Pharmacognosy, v.16, p.408-420, 2006.

BELEFANT-MILLER, H. Poultry litter induces tillering in rice. Journal of Sustainable Agriculture, v.31, n.1, p.151-160, 2007.

CARPIO, L.A.; DAVIES JR, F.T.; ARNOLD, M.A. Arbuscular mycorrhizal fungi, organic and inorganic controlledrelease fertilizers: Effect on growth and leachate of container-grown bush morning glory (Ipomoea carnea ssp. fistulosa) under high production temperatures. Journal of the American Society for Horticultural Science, v.130, p.131-139, 2005.

CARVALHO, P.E.R. Espécies florestais brasileiras: recomendações silviculturais, potencialidades e uso da madeira. Brasília: EMBRAPA, CNPF, 1994. 640p.

CAVALHER-MACHADO, S.C. et al. The anti-allergic activity of the acetate fraction of Schinus terebinthifolius leaves in IgE induced mice paw edema and pleurisy. International Immunopharmacology, v.8, p.15521560, 2008.

CERUKS, M. et al. Constituintes fenólicos polares de Schinus terebinthifolius Raddi (Anacardiaceae). Química Nova, v.30, n.3, p.597-599, 2007.

DEGÁSPARI, C.H.; WASZCZYNSKYJ, N.; PRADO, M.R.M. Atividade antimicrobiana de Schinus terebinthifolius Raddi. Ciência e Agrotecnologia, v.29, n.3, p.617622, 2005.

DI STASI, L.C. et al. Medicinal plants popularly used in the Brazilian Tropical Atlantic Forest. Fitoterapia, v.73, p.69-91, 2002.

EL-MASSRY, K.F. et al. Chemical compositions and antioxidant/antimicrobial activities of various samples prepared from Schinus terebinthifolius leaves cultivated in Egipt. Journal of Agricultural and Food Chemistry, v.57, n.12, p.5265-5270, 2009.

GASKELL, M. et al. Soil fertility management for organic crops. Univ. California Publ. 7249, 2006.

GOBBO-NETO, L.; LOPES, N.P. Medicinal plants: factors of influence on the content of secondary metabolites. Química Nova, v.30, n.2, p.374-381, 2007.

GUNDIDZA, M. et al. The chemical composition and biological activities of essential oil from the fresh leaves of Schinus terebinthifolius from Zimbabwe. African Journal of Biotechnology, v.8, n.24, p.7164-7169, 2009.

HARTZ, T.K.; JOHNSTONE, P.R. Nitrogen availability from high-nitrogen containing organic fertilizers. HortTechnology, v.16, p.39-42, 2006.

ISIDOROV, V.A. et al. Group identification of essential oils components using partition coefficients in a hexaneacetonitrile system. Journal of Chromatography A, v.814, p.253-60, 1998.

JALALI, M.; KHANBOLUKI, G. Redistribution of zinc, cadmium, and lead among soil fractions in a sandy calcareous soil due to application of poultry litter. Environmental Monitoring and Assessment, v.136, p.327-335, 2008.

KELLEY, K.M.; BIERNBAUM, J.A. Organic nutrient management of greenhouse production of edible flowers in containers. HortScience, v.35, p.453, 2000.

LENZI, M.; ORTH, A.I. Caracterização funcional do sistema reprodutivo da aroeira-vermelha (Schinus terebinthifolius Raddi), em Florianópolis-SC, Brasil. Revista Brasileira de Fruticultura, v.26, n.2, 198201, 2004.

LIMA, L.B. et al. Acute and subacute toxicity of Schinus terebinthifolius bark extract. Journal of Ethnopharmacology, v.126, p.468-473, 2009.

MARCELIS, L.F.M. Sink strength as a determinant of dry matter partitioning in the whole plant. Journal of Experimental Botany, v.47, p.1281-1291, 1996.

MAU, J.L. et al. Composition and antioxidant activity of the essential oil from Curcuma zedoaria. Food Chemistry, v.82, p.583-591, 2003.

MONEAM, N.M.A.; GHONEIM, T. Gas chromatographic analysis of total 1 fatty acids extracted from $S$. terebinthifolius berries. Journal of Chromatography, v.361, p.391-395, 1986.

MÜLLER, I.; SCHMID, B.; WEINER, J. The effect of

Rev. Bras. PI. Med., Campinas, v.16, n.2, supl. I, p.398-405, 2014. 
nutrient availability on biomass allocation patterns in 27 species of herbaceous plants. Perspectives in Plant Ecology, Evolution and Systematic, v.3, n.2, p.115-127, 2000.

MULLINS, G.L.; BENDFELDT, E.S. Poultry litter as a fertilizer and soil amendment. 424-034. Virginia Cooperative Extension: Blacksburg, 2001.

OGAYA, R.; PEÑUELAS, J. Species-specific drought effects on flower and fruit production in a Mediterranean holm oak Forest. Forestry, v.80, n.3, p.351-357, 2007.

PIRES, O.C. et al. Análise preliminar da toxicidade aguda e dose letal mediana $\left(D_{50}\right)$ comparativa entre os frutos de pimenta-do-reino do Brasil (Schinus terebinthifolius Raddi) e pimenta do reino (Piper nigrum L.). Latin American Journal of Pharmacy, v.23, p.176-182, 2004.

RENISUS. Relação Nacional de Plantas Medicinais de Interesse ao SUS. Plantas medicinais que apresentam potencial para gerar produtos de interesse ao SUS. Ministério da Saúde. Disponível em: <http://portal.saude.gov.br/portal/arquivos/pdf/ RENISUS.pdf>. Acesso em: 15 Jul. 2010.

RICHTER, R. et al. Spirocyclopropane-type sesquiterpene hydrocarbons from Schinus terebinthifolius Raddi. Phytochemistry, v.71, p.1371-1374, 2010.

TEPE, B. et al. Antibacterial and antioxidative activities of the essential oils and methanol extracts of Salvia cryptantha (Montbret et Aucher ex Benth.) and Salvia multicaulis (Vahl). Food Chemistry, v.84, p.519-525, 2004.

WATT, J.M.; BREYER-BRANDWIJK, M.G. The medicinal and poisonous plants of Southern and Eastern Africa. Edinburgh/London: Livingstone, 1962.

$\mathrm{XIAO}, \mathrm{K}$; YU, D.; WANG, J. Habitat selection in spatially heterogeneous environments: a test of foraging behavior in the clonal submerged macrophyte Vallisneria spiralis. Freshwater Biology, v.51, p.1552-1559, 2006. 